\title{
MAJIĆA GRADINA (DRINOVCI) - NOVO NALAZIŠTE LICENSKE KERAMIKE U HERCEGOVINI
}

Tino TOMAS

Filozofski fakultet

Odjel za arheologiju

Matice hrvatske b.b.

$\mathrm{BiH}$ - 88000 Mostar

E-pošta: tomas.tino@yahoo.com
UDK 903-033.64(497.6 Drinovci)"637" Izvorni znanstveni rad Primljeno: 29. veljače 2016 Prihvaćeno: 8. lipnja 2016.

\section{Sažetak}

U radu se donose rezultati analize keramičkoga ulomka pronađenoga na Majića gradini (Drinovci). Iako promatrani ulomak nema stratigrafsku potvrdu, zahvaljujući svojim, prije svega ornamentalnim obilježjima, predstavlja snažan i pouzdan kronološki reper brončanoga doba kulturne regije. Prvenstveno u toj činjenici se i krije njegova važnost.

Ključne riječi: Majića gradina, litzen i schnur keramika, posuška kultura, brončano doba, Drinovci, Hercegovina. 
Majića gradina smještena je na južnom obodu Imotsko-bekijskoga polja, u mjestu Drinovci, u naselju Sebišina. Na samoj državnoj granici između Federacije Bosne i Hercegovine i Republike Hrvatske, odnosno Hercegovine i Dalmacije. ${ }^{1}$ Gradina je podignuta na izdvojenom platou (k. 478) koji se nalazi u sklopu većega brdskog masiva. ${ }^{2}$ Plato gradine ima približno ovalnu formu površine 130 x 90 metara. Ostatci fortifikacijskoga sustava u vidu kamenih bedema rađenih u tehnici suhozida, u većoj mjeri su sačuvani na zapadnoj i južnoj, te dijelom i na sjevernoj strani gradine. Odnosno na mjestima gdje je i postojala realna potreba za njihovo podizanje. Za razliku od istočne strane, gdje se teren spušta pod znatno većom inklinalom, čime je pristup gradini znatno otežan. Kulturni sloj na gradini u većoj mjeri je sačuvan jedino na njezinu sjevernom dijelu u vidu veće artificijelne zaravni, dok je na ostatku gradine dijelom uništen djelovanjem prirodnih mehaničkih sila, a na onim mjestima s većim površinama matične stijene nije niti postojao. $S$ aspekta korištenja unutarnjih prostornih potencijala Majića gradine zanimljive su i dvije vrtače smještene na njezinu južnom dijelu. Bez arheoloških iskopavanja u ovom trenutku nije moguće donijeti više podataka u smislu određivanja uže kulturne i kronološke pozicije Majića gradine i organizacije njezina unutarnjeg prostora. Stoga se moramo zadovoljiti dostupnim arbitrarnim terenskim podatcima, koji nude ograničene

1 Iako spomenuta granica de facto gradinu dijeli na dva dijela, sam naziv gradine, terenski i katastarski podatci indiciraju kako je njezin uži prostor gravitirao obližnjem zaseoku Majići, koji se nalaze na teritoriju Federacije Bosne i Hercegovine. Slični toponimi koji vežu osobna imena uz prirodne i kulturne pojave nisu rijetkost. Mahom ih susrećemo u blizini recentnijih naselja, a nastaju iz potrebe markiranja vlasničkih pretenzija i organizacije imovinskih odnosa.

2 Z. Marić Majića gradinu navodi taksativno, spominjući je kao Gradinu kod Drinovaca, područje Sebišina, općina Grude. ZdRAVKo MARIć, "Prahistorijska i protohistorijska utvrđenja na području Daorsa", u: Posebna izdanja, XXIV/6, Centar za balkanološka ispitivanja, Sarajevo, 1975., karta 1. Nešto kasnije I. Bojanovski spominje je kao prostornu dominantu, u kontekstu dijela trase rimskoga magistralnog puta Akvileja - Dirahij, koji je prolazio otprilike 400 metara sjeverno, ispod gradine. S tim kako je kota, tj. točna nadmorska visina gradine tom prilikom pogrješno navedena. Ivo BoJANovski, "Prilozi za topografiju rimskih i predrimskih komunikacija i naselja u rimskoj provinciji Dalmaciji", u: Godišnjak, XV/7, Centar za balkanološka ispitivanja, Sarajevo, 1977., str. 100. Nadalje, sumarane podatke o gradini donosi Tihomir Glavaš, prilikom čega gradinu na temelju površinskih nalaza smješta u širi kronološki okvir brončanoga i željeznoga doba. Usp. Tinomir Glavaš, "Gradina", u: Arheološki leksikon Bosne i Hercegovine, tom 3, reg. 25. 118., Sarajevo, 1988., str. 326. 
mogućnosti. ${ }^{3}$ Kao što je i inače dokumentirana praksa kod nalazišta gradinskoga tipa na prostoru šire kulturne regije, i na primjeru Majića gradine je sasvim evidentno kako je maksimalno i na efektan način iskorišten prirodni položaj, u svrhu zadovoljavanja osnovnih koncepata nalazišta gradinskoga tipa. Kontrole prostora u smislu uspostavljanja odgovarajućih mikro strateških, prostornih, odnosno vizualnih odnosa u okruženju, ${ }^{4}$ dostupnosti osnovnih životnih resursa kao osnove za razvoj materijalne i duhovne kulture, te izbjegavanja negativnih utjecaja okoline. ${ }^{5}$ Svakako da Majića gradina ne izlazi iz okvira fenomena gradinskih nalazišta s prostora šire kulturne regije, čiju pojavu promatramo kroz prizmu složenih društvenih odnosa i procesa komuniciranja, a dijelom i kulturne tradicije i iskustva.

Prilikom terenskoga pregleda širega prostora Majića gradine pronađeno je više keramičkih ulomaka. Svi keramički ulomci pronađeni su na sjevernom i sjeveroistočnom dijelu gradine, odnosno onom dijelu za koji je već ustanovljeno kako sadrži znatniju površinu sačuvanoga kulturnog sloja. Redom se radi o atipičnim ulomcima koji ne sadrže elemente relevantne za određivanje njihove uže kulturne i kronološke atribucije. Pronađeni keramički ulomci imaju karakter površinskih nalaza, bez jasno određene prostorne i vremenske relacije unutar nalazišta, te zbog toga značajno gube u ukupnom potencijalu znanstveno upotrebljivih podataka koje mogu sadržavati.

3 U širem prostornom, a dijelom možda i vremenskom i kulturnom kontekstu Majića gradine, treba spomenuti još dva nalazišta gradinskoga tipa u blizini. Vrcanovu gradinu (k. 350) cca. 2 kilometra sjeveroistočno (CARL PATsch, "Rimska mjesta u Imotskom polju", u: Glasnik Zemaljskog muzeja, XII., Sarajevo, 1900., str. 343) i gradinu na brdu Babnjača (k. 692) cca. 1 kilometar južno od Majića gradine. Te naravno više kamenih gomila u blizini za koje možemo s pravom pretpostaviti kako su neke od njih potencijalno mogle biti involvirane u aktivnosti zajednice/a koje su gravitirale Majića gradini. Usp. ŠEFIK BEŠLAGIć, Stećci - Kataloško topografski pregled, Veselin Masleša, Sarajevo, 1971., str. 303; I. BoJANovski, nav. dj., str. 99; Ljubomir GudelJ, "Arheološka slika Zmijavaca - Razmatranja u povodu zaštitnih istraživanja iz godine 2005.", u: Starohrvatska prosvjeta, III/39, Split, 2012., sl. 3. Naravno, bez provođenja arheoloških iskopavanja, navedeno smo primorani ostaviti na razini pretpostavke.

4 U tom smislu svakako je indikativan spomenuti rimski put koji prolazi u neposrednoj blizini koji je mogao nastati na osnovi prapovijesne komunikacije. I. BoJANOVSKI, nav. dj., str. 139-141.

5 Hrvoje Potrebica, "Prostorne odrednice prapovijesnih naselja", u: Histria antiqua, 11, Pula, 2003., str. 159 i d. 


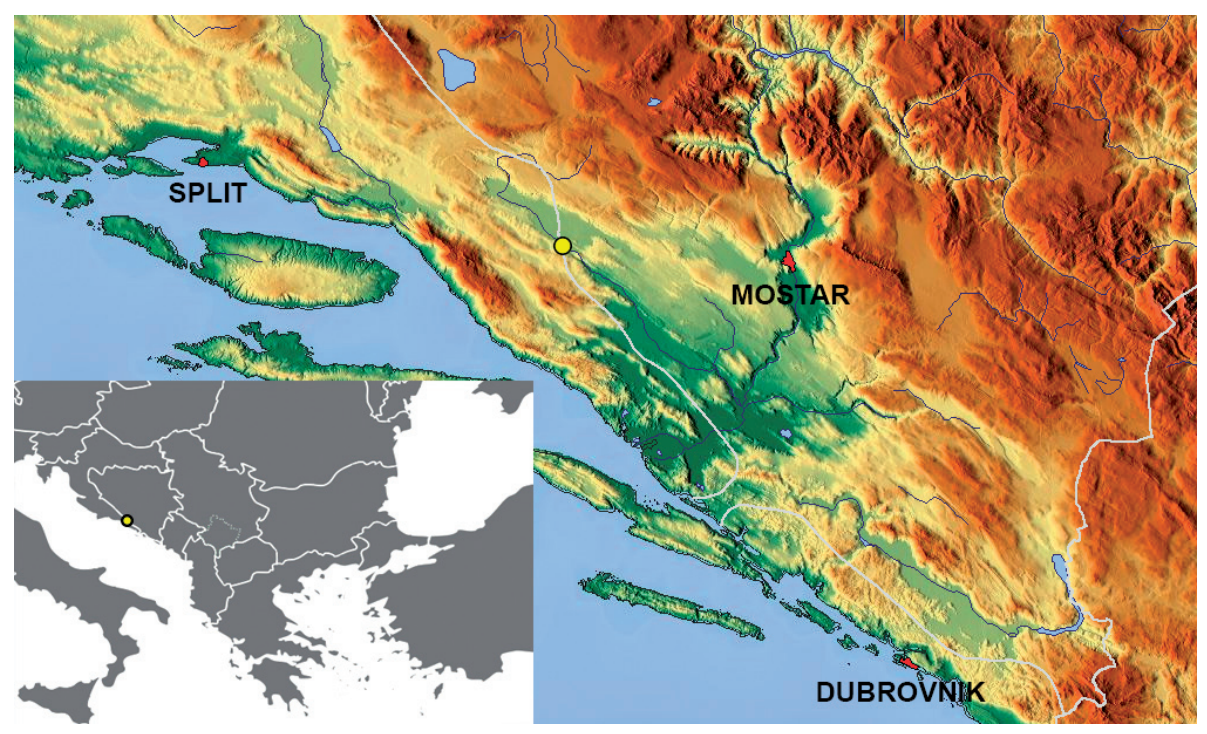

Karta 1. Širi geografski položaj Majića gradine (izvor: Google Maps - Relief Layers, prilagodio: autor)

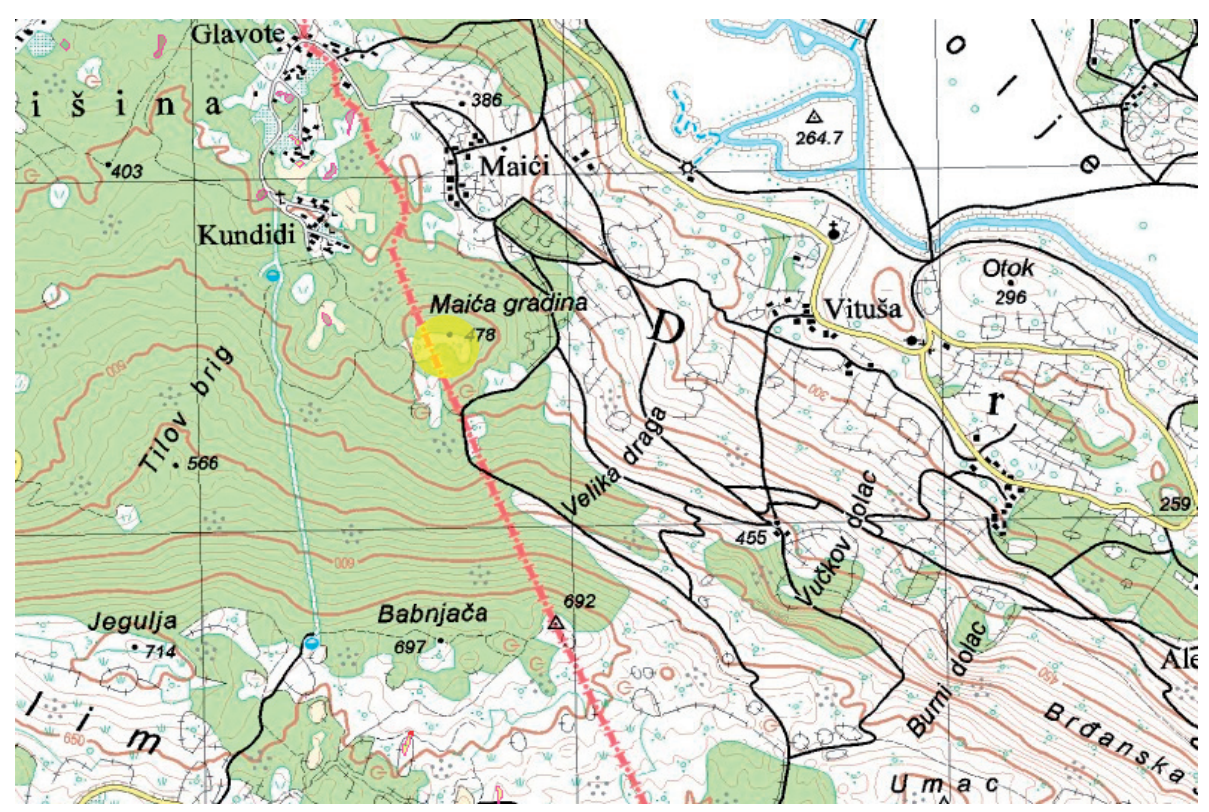

Karta 2. Topografski položaj Majića gradine, 1:25000 (izvor: Arcod, prilagodio: autor) 


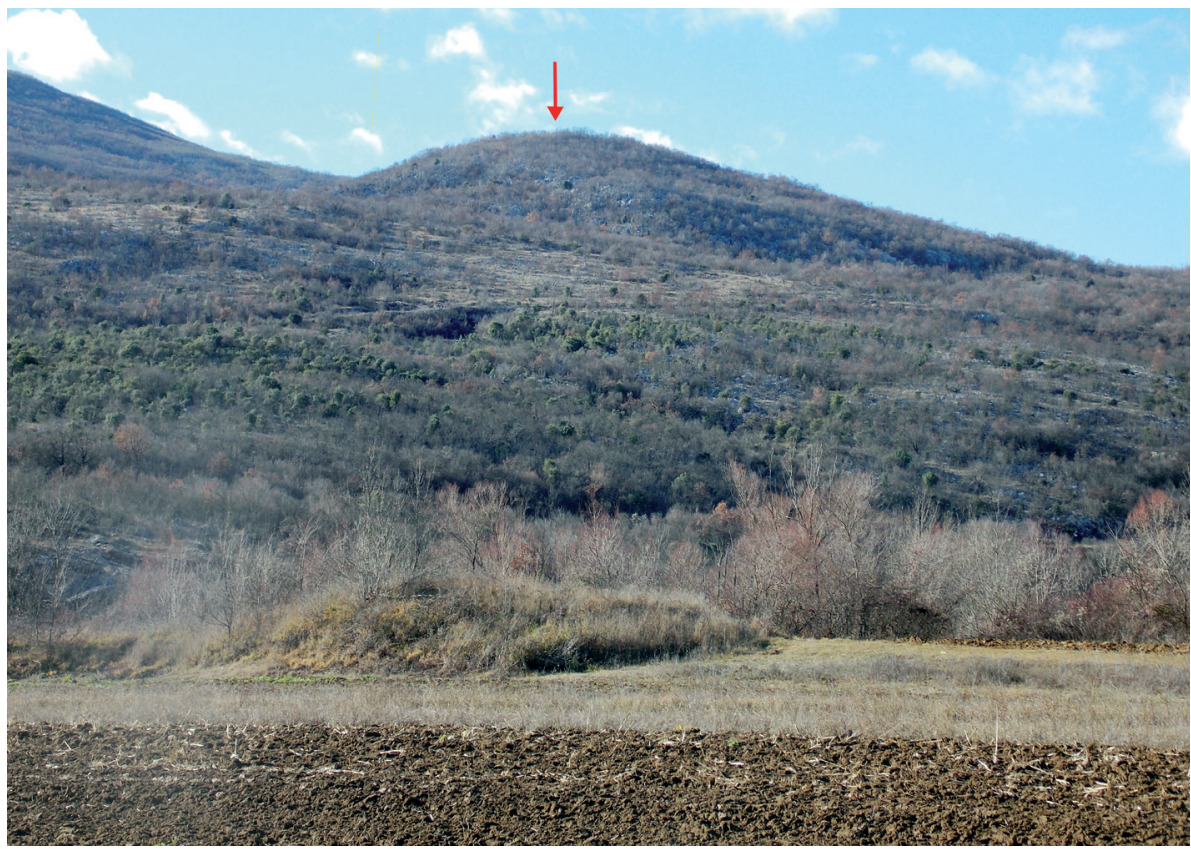

Slika 1. Pogled na Majića gradinu sa sjevera (fotografirao: autor)

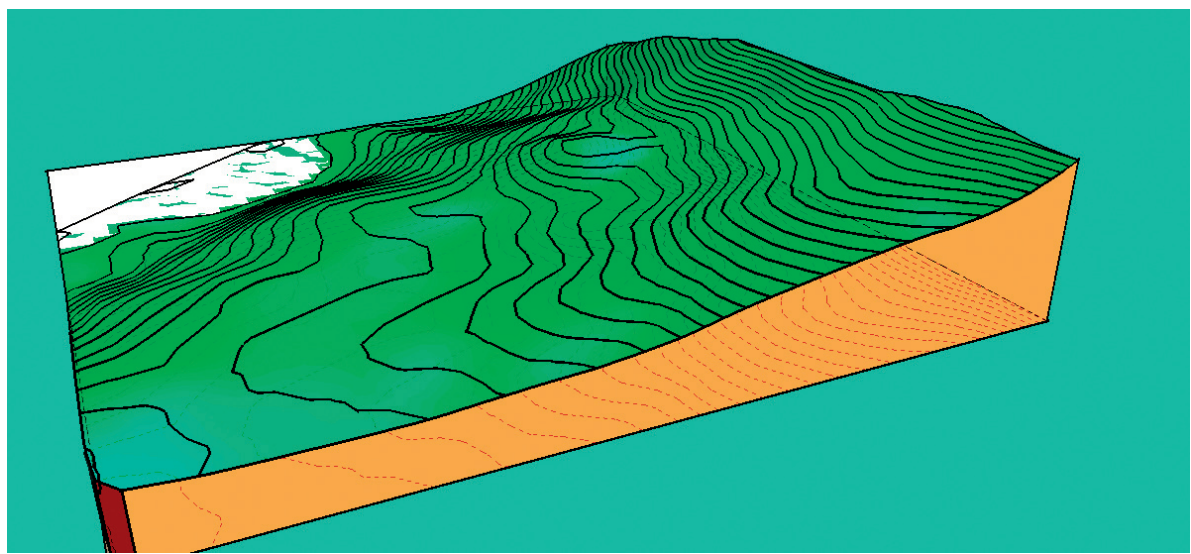

Slika 2. Digitalni model reljefa užega prostora Majića gradine (izradio: autor) 


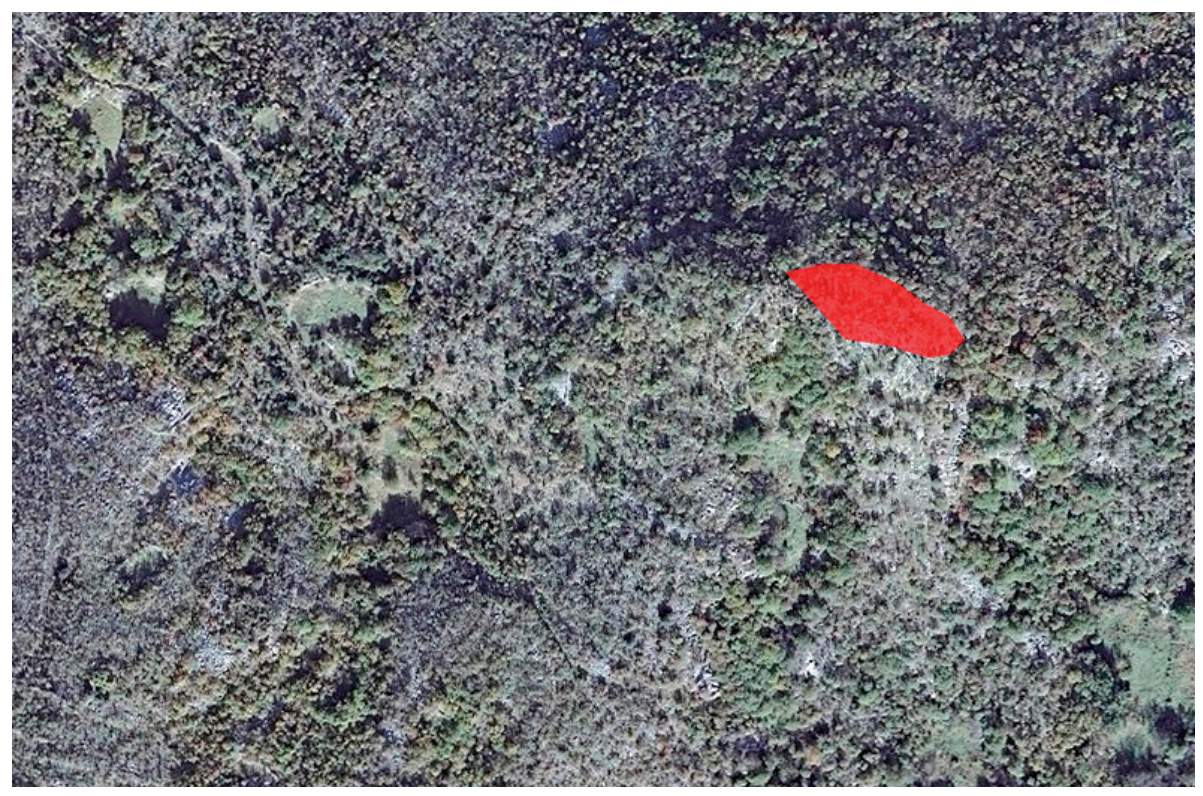

Slika 3. Ortofoto snimka Majića gradine s označenim sjevernim dijelom na kojemu je dokumentirana znatnija površina kulturnoga sloja (izvor: Geoportal / Katastar.ba, prilagodio: autor)

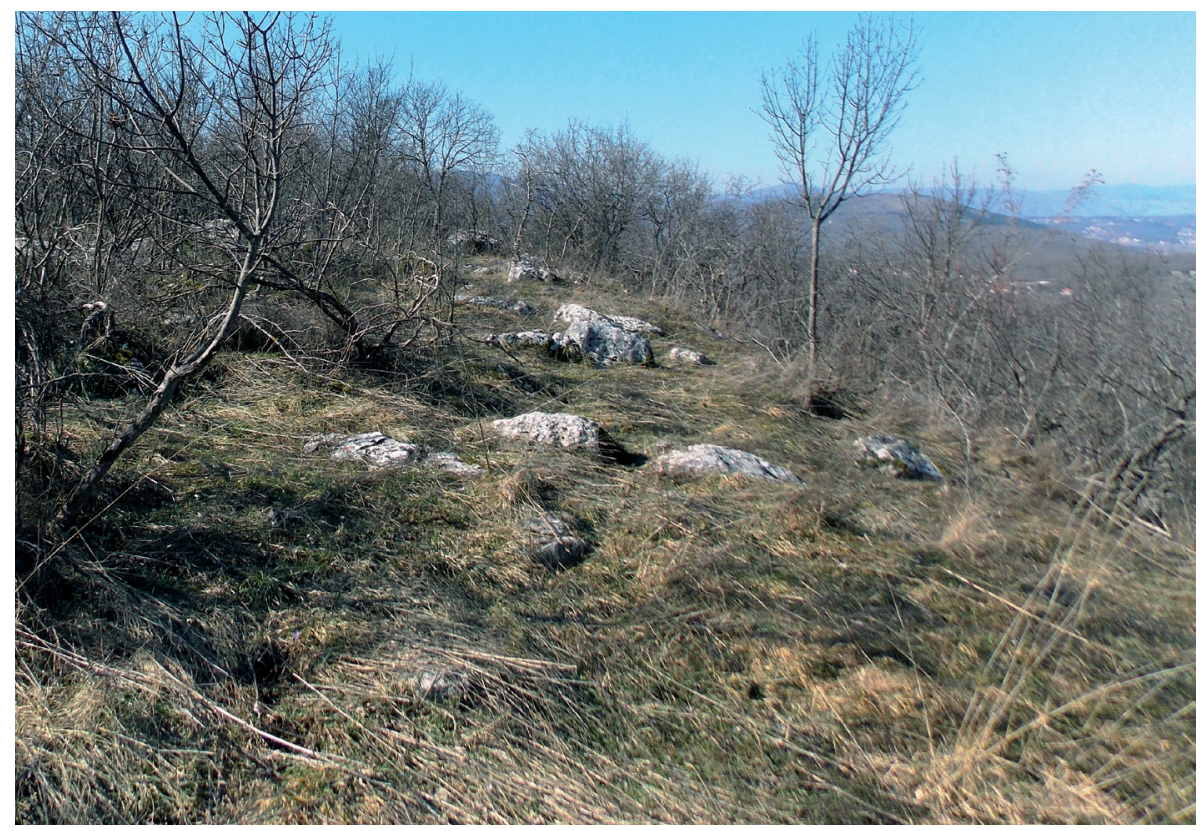

Slika 4. Pogled na sjeverni dio Majića gradine (fotografirao: autor) 
Ipak, jedan ulomak zaslužuje posebnu pažnju zbog svojih tipoloških, a osobito ornamentalnih obilježja. Radi se o ulomku gornjega dijela posude, točnije dijelu vrata otprilike stožaste forme, s nepravilnim neznatno izvijenim i s vanjske strane ojačanim obodom. Boja površine ulomka varira od tamno smeđe, sive, do oker. S vanjske i unutarnje strane, ${ }^{6} \mathrm{~s}$ tim kako vanjska i unutarnja površina ulomka pokazuju tragove solidnog glačanja. Najizglednije kako je prilikom ponovnoga glačanja (kako bi se izbrisali tragovi utiskivanja) došlo i do djelomičnoga brisanja ornamenta, što je vidljivo i na našem ulomku. ${ }^{7}$ Ulomak je izrađen od dobro pročišćene gline s neznatnim tragovima primjesa, debljina zidova je relativno tanka, a presjek pokazuje ujednačen tonus svijetlo sive boje. ${ }^{8}$ Posebno se ističe ornament položen na vratu posude. Izveden je utiskivanjem složenijega tekstilnog uzorka u još svježu, nepečenu površinu posude, a sastoji se od kombinacije valovito i vodoravno položenih otisaka-motiva. Navedeni ornament, prema svojim tehničkim obilježjima i motivici, uklapa se u poznati fundus licenske keramike, koja predstavlja rijedak, pouzdan kronološki i kulturni reper u okviru brončanoga doba promatrane kulturne regije.

Kao posebna kulturna pojava licenska keramika je u prvom redu izdvojena na prostoru Austrije 30-ih godina prošloga stoljeća. Najveća koncentracija nalaza licenske keramike, osim na prostoru Austrije (posebice istočne Austrije, s naglaskom na Donju Austriju), dokumentirana je na prostoru Mađarske (osobito Transdanubije) i sjeverne Hrvatske, na tim prostorima licenska keramika smatra se samostalnom kulturnom

6 Neujednačen tonus površine pronađenoga ulomka možemo pripisati kombinaciji materijala od kojega je keramika izrađena, tehnološkoga postupka pečenja kojemu je bila podvrgnuta i različitim utjecajima okoliša kroz dugo razdoblje (tim više jer se radi o površinskom nalazu).

7 Usp. Marko Dizdar, "Brončanodobno naselje u Vinkovcima - Duga ulica br. 23.", u: Opuscula archaeologica, 20, Zagreb, 1996., str. 13. Slične tragove pokazuju i neki ulomci iz kulturne regije. Usp. Borivoj Čović, "Posuška kultura", u: Glasnik Zemaljskog muzeja (A), n. s., sv. 44, Sarajevo, 1989., T. X, 5; Brunislav MARIJANOvić, Ravlića pećina - prapovijesno naselje, Mostar, 2012., T. LXXXV, 5; T. LXXXVI, 1.

8 S obzirom kako se ne radi o naknadnom premazu, razlike u boji površine i presjeka svakako su posljedica tehnološkoga postupka pečenja kojem je keramika bila podvrgnuta, u ovom slučaju postupku tzv. nepotpune oksidacije Usp. ZRINKA Šimić-KanAET, "Razvoj lončarskih peći i tehnologije pečenja na prapovijesnim i antičkim primjerima", u: Opuscula archaeologica, 20, Zagreb, 1996., str. 151 i d.; Romuald Zlatunić, "Nastanak gline, tehnologija i mineralogija keramike", u: Histria archaeologica, 36, Pula, 2005., str. 95-96. 


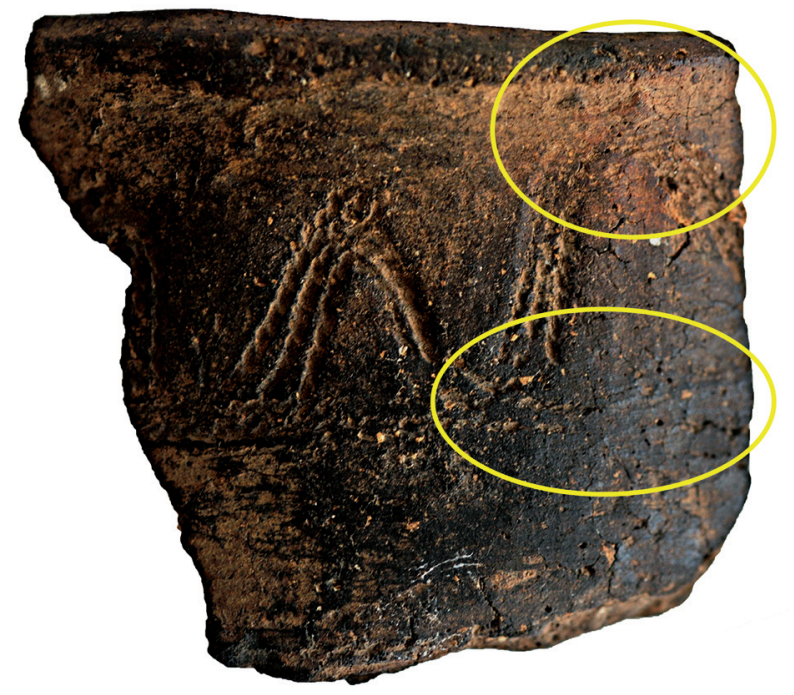

Slika 5. Tragovi naknadnoga glačanja površine na promatranom ulomku (fotografirao: autor)

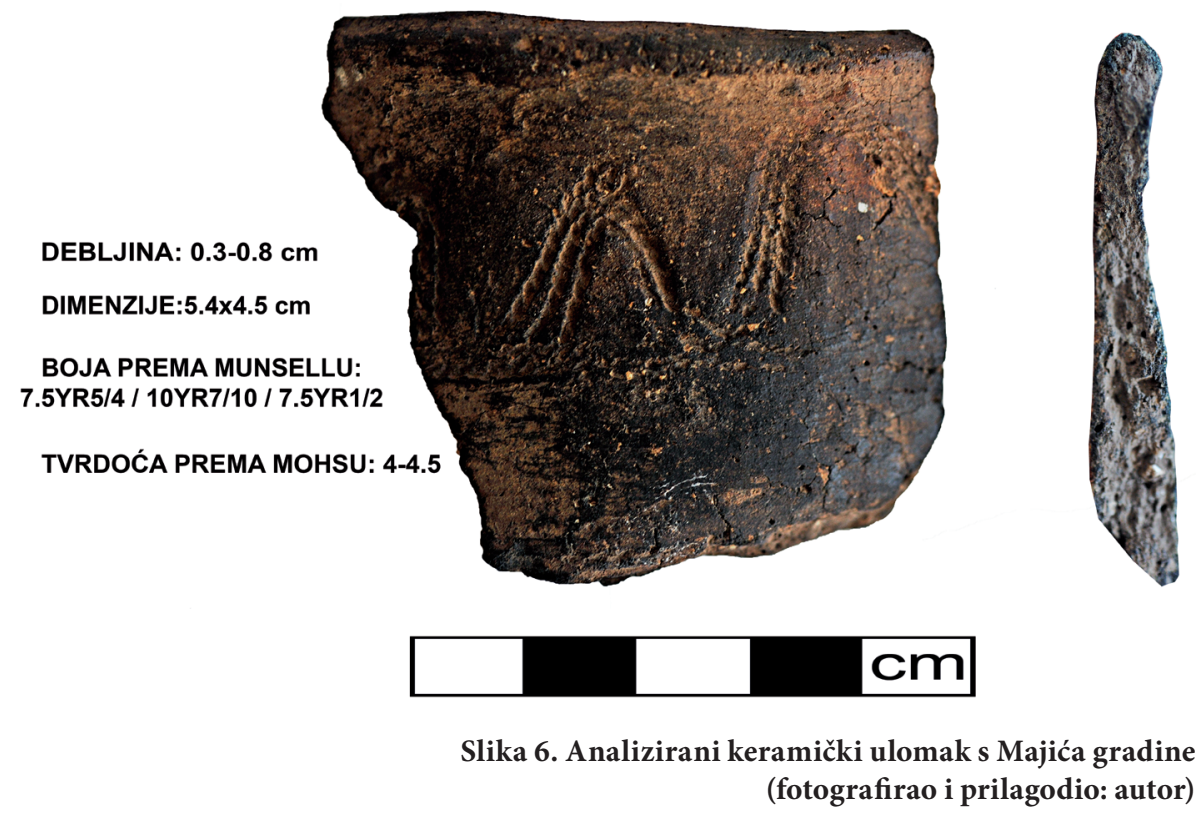




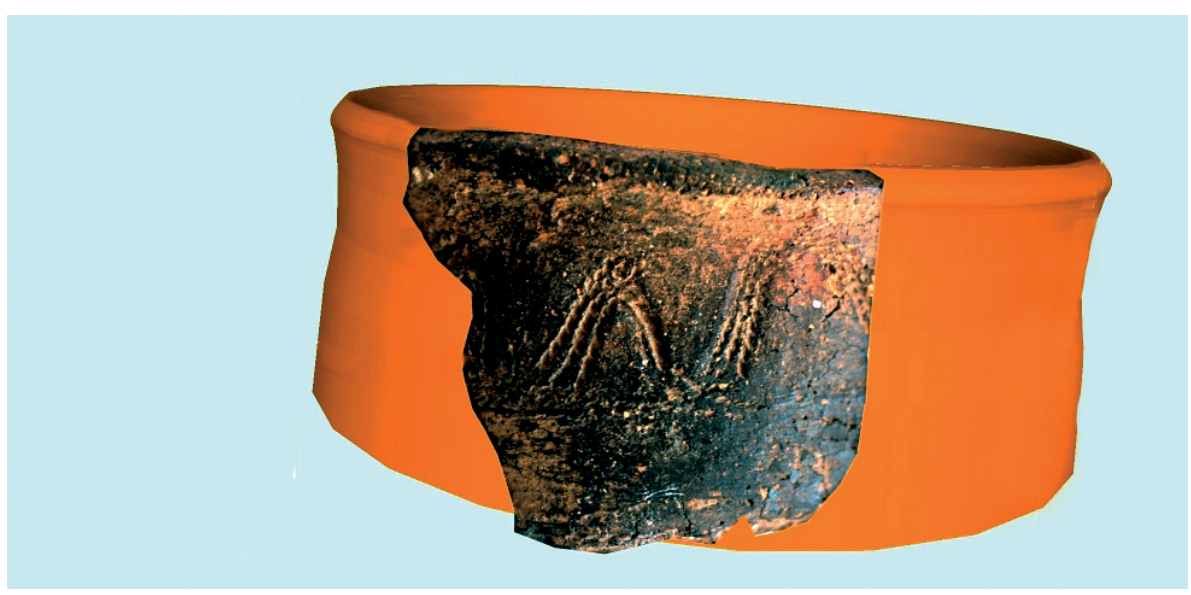

Slika 7. 3-D rekonstrukcija vratnoga segmenta posude s pronađenim ulomkom (izradio: autor)

pojavom, ${ }^{9}$ osim spomenutoga, jugoistočno-alpskoga i zapadno-panonskoga prostora koji se smatra matičnim arealom licenske keramike. Kao import i jedna od važnijih komponenti kultura ranoga i srednjega brončanog doba, licenska keramika se javlja na prostoru Slovačke, Slovenije, Slavonije, Vojvodine (Srijema), srednje Bosne, Hercegovine i srednje Dalmacije, te mjestimice na prostoru istočne Bosne i sjevernoga Jadrana. ${ }^{10}$ Sam pojam litzenkeramik uvodi Kurt Willvonseder na temelju tehnološkoga postupka izvedbe samoga ornamenta ${ }^{11} \mathrm{o}$ kojem su kroz povijest istraživanja licenske keramike kreirana prilično divergentna mišljenja. ${ }^{12}$

9 Usp. Marijana Martinec, "Brončanodobna naseobinska jama s lokaliteta Grabrovac", u: Opuscula archaeologica, 26, Zagreb, 2002., str. 277; BošKo MARIJAN, "Nalazi keramike s licenskim ukrasima u županjskom kraju", u: Opuscula archaeologica, 27, Zagreb, 2003., str. 115; ZORKo MARKović, "O genezi i počecima licenskokeramičke kulture u sjevernoj Hrvatskoj", u: Opuscula archaeologica, 27, Zagreb, 2003., str. 117 i d.

10 M. Martinec, nav. dj., str. 277 i citirana literatura.

11 Općenito o licenskoj keramici usp. Zoja Benkovsky-Pivovarova, "Zur Problematik der Litzenkeramik in Österreich", u: Praehistorische Zeitschrift, 47/2, Berlin, 1972., str. 198-212; KsENIJA VINSKi GASPARINI, "Litzen keramika savsko dravskog međuriječja", u: AloJz BenAC (prir.), Praistorija jugoslavenskih zemalja, IV., Centar za balkanološka ispitivanja, Sarajevo, 1983., str. 484; M. MarTineC, nav. dj., str. 276; Z. MARKović, nav. dj., str. 118 i d.

12 Stojan Dimitrijević, "Ljubljanska kultura ili dalji život vučedolske baštine", u: Alojz Benac (prir.), Praistorija jugoslavenskih zemalja, III., Centar za balkanološka ispitivanja, Sarajevo, 1979., str. 320, 325; K. VINSKI GASPARINI, nav. dj., str. 484; Borivoj Čović, "Schnur i litzen keramika na području Neretve", u: ŽELJKo 


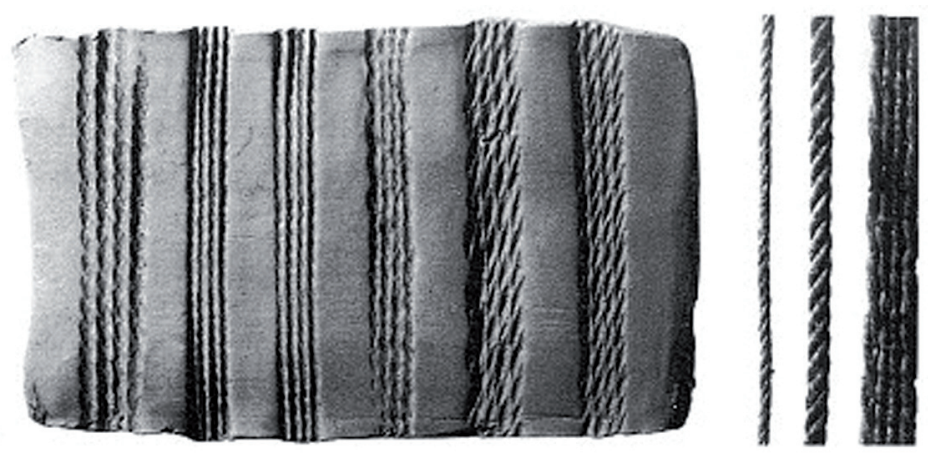

Slika 8. Pokusni otisci dvonitne uzice i otkane vrpce u svježu glinu (prema: Johannes-Wolfgang Neugebauer, "Litzenkeramik oder Draßburger Kultur - V", u: Johannes-Wolfgang Neugebauer (prir.), Bronzezeit in Ostösterreich, St. Pölten-Wien, 1994., Abb. 77, 4)

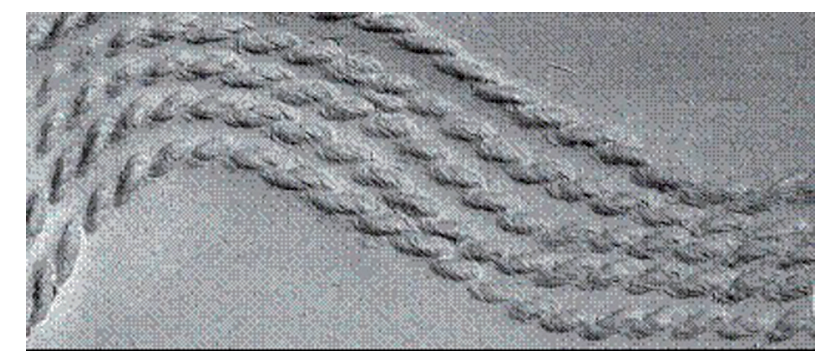

Slika 9. Otisci motiva valovnice izvedene utiskivanjem dvonitne uzice (prema: ElENE LEgHissA, "Način okraševanja keramike ljubljanske kulture in pramenaste keramike - eksperimentalna arheologija", u: Arheološki vestnik, 66,

Ljubljana, 2015., sl. 9, b)

Ornament na promatranom ulomku izveden je višestrukim utiskivanjem fine, uske uzice, izrađene od dvije spletene niti, koja je ostavila uske i sitne otiske. ${ }^{13}$ Ornament izveden utiskivanjem dvonitne uzice,

RAPANIĆ (prir.), Dolina Neretve od prethistorije do ranog srednjeg vijeka, Izdanja Hrvatskoga arheološkog društva, vol. 5, Split, 1980., str. 41, bilj. 1; BorıvoJ Čović, Pod kod Bugojna - Naselje bronzanog i željeznog doba u centralnoj Bosni, sv. 1.: Rano bronzano doba, Sarajevo, 1991., str. 20-21; M. Dizdar, nav. dj., str. 13; Z. MARKović, nav. dj., str. 123.

$13 \mathrm{Na}$ nalazištu Ig (Slovenija), gdje također imamo nalaze licenske keramike, pronađeni su i ostatci dvostruko spletenih uzica biljnoga porijekla, izrađenih od vlakana lista rogoza, močvarne trave ili lana. Isto tako, slične uzice mogle su biti izrađene 
prema svemu sudeći stoji u uskoj vezi s licenskim ornamentom, ${ }^{14}$ iako treba razlikovati, u tehničkom i terminološkom pogledu ukras izveden otiskom prave otkane vrpce/tkanice (die litze, i. e. licena) od onoga izvedenog od dvonitne uzice (schnur). ${ }^{15} \mathrm{U}$ kulturnom i kronološkom pogledu navedene razlike nisu toliko izražene, barem ne u kontekstu promatrane kulturne regije, gdje često i ne postoji uža distinkcija prema načinu izvođenja ornamenta, nego se konvencionalno takva vrsta nalaza, bilo da su oni ukrašeni otiskivanjem dvonitne uzice ili otkane tkanice/vrpce, često deklarira kao licenska. ${ }^{16}$

i od materije životinjskoga podrijetla (dlake). Elene Leghissa, "Način okraševanja keramike ljubljanske kulture in pramenaste keramike" - eksperimentalna arheologija, u: Arheološki vestnik, 66, Ljubljana, 2015., str. 280. U tom kontekstu zgodno je spomenuti i rezultate do kojih su došle M. Krmpotić i M. Vuković Biruš, prema kojima su takve uzice najizglednije bile izrađivane tehnikom tkanja uz pomoć pločica. Usp. Marijana Krmpotić - Maša Vuković Biruš, "Arheološki eksperiment: Vrpčasti ukrasi na ulomcima starije faze grupe Belegiš, s lokaliteta Josipovac Punitovački - Veliko polje I", u: LEA ČATAJ (prir.), Josipovac Punitovački - Veliko polje I, zaštitna arheološka istraživanja na trasi autoceste A5, eneolitičko, brončanodobno i srednjovjekovno naselje, Hrvatski restauratorski zavod, Zagreb, 2009., str. 260-262.

14 Npr. B. Čović i Z. Marković ornamente izvedene utiskivanjem dvonitne uzice nazivaju vrpčastima (schnur) i pseudovrpčastima. Usp. B. Čović, Pod kod Bugojna - Naselje bronzanog i željeznog doba u centralnoj Bosni, sv. 1: Rano bronzano doba, str. 20; Z. MARković, nav. dj., str. 123. Dok M. Dizdar iste ornamente naziva pseudovrpčastim. Usp. M. Dizdar, nav. dj., str. 13. Navedenu tvrdnju svakako moramo promatrati kao reflekt genetskih procesa licenske keramike. Prije svega snažnih utjecaja Kisapostag kulture i kasnovrpčastih kultura na njezinu matičnom prostoru. Usp. M. MARTINeC, nav. dj., str. 282 i citirana literatura.

15 B. Čović, Pod kod Bugojna - Naselje bronzanog i željeznog doba u centralnoj Bosni, sv. 1: Rano bronzano doba, str. 20-21; M. Dizdar, nav. dj., str. 12-14; Z. MARKOvić, nav. dj., str. 123-124, 128-129.

16 Usp. B. Čović, "Posuška kultura", 70, 75, 77-78, T. VIII, 5, T. X, 5, 4; Marinko TOMAsović, "Arheološka topografija lijeve strane donjeg toka Cetine", u: JACQUeline Balen - Hrvoje Potrebica (prir.), Arheološka istraživanja u cetinskoj krajini, Izdanja Hrvatskoga arheološkog društva, vol. 27, Zagreb, 2011., T. I, 5-6; Vedran Katavić - Ana Sunko Katavić - Andrea Devlahović, "Istraživanje grobnog tumula, dviju vrtača, gradine i gradinice u Gornjim Rašćanima kod Vrgorca", u: MARInko Tomasović (prir.), Arheološka istraživanja na trasi autoceste u Zabiokovlju i Plini, Makarska, 2011., str. 46, kat. jed. 7; Konstanta Mucić Nela Kovačević BoKarica, "Doprinosi poznavanju povijesti Vrgoračke krajine na osnovi rezultata novijih arheoloških istraživanja", u: MARINko Tomasović (prir.), Arheološka istraživanja na trasi autoceste u Zabiokovlju i Plini, Makarska, 2011., str. 130, kat. jed. 2; B. MARIJAnović, nav. dj., str. 105, T. LXXXV, 5; T. LXXXVI, 1,2; Ivan ŠUta, "Korištenje vrtača u prapovijesti Dalmacije", u: Tusculum, 6, Solin, 2013., str. 11-12, sl. 6. 
Najbliže analogije pronađenom ulomku, kako u tipološko-stilskom, tako i u prostornom kontekstu pronalazimo u okviru posuške kulture. ${ }^{17}$ Forme keramičkih posuda s cilindričnim vratom i s neznatno izvijenim obodom predstavljaju nasljeđe iz vremena razvijenoga eneolitika, a poznate su još iz Nečajno faze posuške kulture, te se javljaju i u sljedećoj Sovići fazi. ${ }^{18}$ Posude ukrašene licenskom ornamentikom predstavljaju relativno čest nalaz unutar keramografije posuške kulture. S naglaskom kako postaju jedna od najvažnijih determinanti Sovići faze (e. g. na eponimnom nalazištu Trostruka gradina u Sovićima gotovo $3 / 4$ keramike srednje i fine fakture otpada na keramiku ukrašenu licenskim ornamentom). ${ }^{19}$ Ornament je po pravilu koncentriran na gornji dio posude (rame i vrat) i ručke, a mogao je biti ispunjen bijelom inkrustacijom. ${ }^{20} \mathrm{Za}$ fazu Sovići signifikantna je i pojava složenijega koncepta licenske ornamentike (valovnice u kombinaciji s horizontalno položenim motivima), analogne onoj na našem ulomku. ${ }^{21}$ Važno je naglasiti kako s jednoslojnoga nalazišta Trostruka gradina poznajemo i ornament valovnica izveden utiskivanjem dvonitne uzice, slično kao na našemu primjerku. ${ }^{22}$

Uzevši u obzir podatke s istraženih nalazišta u okviru kulturne regije, $s$ jasno stratificiranim materijalom, pojavu licenske i keramike ukrašene utiskivanjem dvonitne uzice u promatranoj kulturnoj regiji (i. e. u okviru posuške kulture) vežemo za mlađi dio ranoga brončanog doba i početni dio srednjega brončanog doba $\left(\mathrm{Br}_{2}-\mathrm{Br}_{1}\right.$, prema srednjoeuropskoj kronološkoj shemi). ${ }^{23}$ Pri relativno kronološkim razmatranjima, važno je spomenuti i konstataciju B. Čovića kako se licenska keramika ukrašena motivom valovnica na Trostrukoj gradini javlja u donjoj polovici sloja. Što prima faciae otvara indiciju prema kojoj je taj način ukrašavanja, na prostoru promatrane kulturne regije stariji, no ipak s tom konstatacijom treba još pričekati. ${ }^{24} \mathrm{U}$ analizi relativno - kro-

17 U komparativnom smislu osobito su važna istražena nalazišta u blizini Majića gradine: Nečajno, Trostruka gradina i Ravlića pećina.

18 Također i faktura našega ulomka korespondira onoj poznatoj u posuškoj kulturi. Usp. B. Čović, "Posuška kultura", str. 72, 77; B. MARIJAnović, nav. dj., str. 103, T. LXXXII, 1-3; T. LXXXIII, 1-3; T. LXXXVII, 1-4, 6, 12.

19 B. Čović, "Posuška kultura", str. 70, 75, 77 i d.

20 Isto, str. 77.

$21 \mathrm{~S}$ tim kako je općenito pravolinijski licenski ornament dosta češći od krivolinijskog. Isto, 77, T. X, T. XI.

22 Isto, T. X, 5.

23 B. Čović, "Posuška kultura", str. 75, 94-95; B. Marijanović, nav. dj., str. 103.

24 B. Čović, "Posuška kultura", str. 75. U Nečajno (prvoj) fazi posuške kulture licenska keramika nije poznata, iako je na spomenutom eponimnom nalazištu, čiji 
noloških relacija licenske keramike u kulturnoj regiji, treba spomenuti i nalaze licenske keramike, koje vežemo za mlađi ukop u tumulu 1 na nalazištu Živalji (Obrovac kod Sinja). Koji se prema tipološkoj analizi skupnih nalaza (misli se prije svega na triangularni brončani bodež $\mathrm{s}$ punokovinskom drškom) datira u sam kraj stupnja $\mathrm{Br} \mathrm{A}_{2} \cdot{ }^{25}$

Od ostalih nalazišta koja ne ulaze u prostor promatrane kulturne regije. U komparativnom smislu pozicioniranja relativno kronološke relacije promatranoga ulomka, svakako se kao važni reperi izdvajaju višeslojna, sustavno istražena nalazišta, Pod kod Bugojna i Varvara kod vrela Rame. Na nalazištu Pod nalazi licenske i keramike ukrašene utiskivanjem dvonitne uzice (schnur) pozicioniraju se u kratkotrajnu fazu Pod $\mathrm{A}_{2}$, koja korespondira s krajem ranoga i početkom srednjega brončanog doba $\left(\mathrm{Br} \mathrm{A}_{2}-\mathrm{Br} \mathrm{B}_{1}\right){ }^{26}$ Nadalje, na nalazištu Varvara, iako nisu dokumentirani nalazi licenske keramike i keramike ukrašene utiskivanjem dvonitne uzice, od iznimne su važnosti ostali elementi kojima analogije nalazimo na Podu i na nalazištima iz Hercegovine i srednje Dalmacije, a koji se javljaju uz licensku keramiku. Spomenute elemente vežemo za Varvara $\mathrm{A}_{3}$ fazu, koja se datira u završnu fazu ranog i početak srednjeg brončanog doba (i. e. $\left.\mathrm{Br} \mathrm{A}_{2}-\mathrm{Br}_{1}\right){ }^{27}$ Korisno je spomenuti i podatke s prostora sjeverne Hrvatske. Prema Z. Markoviću, koji je prema nalazima iz zatvorenih arheoloških cjelina izdvojio licensku keramiku kao posebnu kulturnu pojavu na tom prostoru, valovnice ukrašene utiskivanjem dvonitne uzice (schnur) tipične su za stupanj-A- klasične licenskokeramičke kulture, koja se datira u mlađi dio ranog brončanog doba $\left(\mathrm{Br} \mathrm{A}_{2}\right) .{ }^{28}$ Prema navedenim pokazateljima relativno kronološka i kulturna pozicija promatranoga ulomka sasvim je jasno određena. Radi se o vremenu druge polovice ranoga brončanog doba i dijelu početka srednjega brončanog doba. U kulturnom smislu to bi bilo vrijeme faze Sovići, posuške kulture.

kulturni sloj u cijelosti pripada Nečajno fazi, pronađen jedan ulomak licenske keramike. No, spomenuti ulomak je pronađen u humusnom površinskom sloju, gdje je mogao dospjeti naknadno. B. Čović, "Posuška kultura", str. 70, T. VIII, 5.

25 Borivoj Čović - Ivan Marović, "Cetinska kultura", u: Alojz Benac (prir.), Praistorija jugoslavenskih zemalja, IV., Centar za balkanološka ispitivanja, Sarajevo, 1983., str. 207-209, 214, T. XXXIV, 1-6.

26 B. Čović, Pod kod Bugojna - Naselje bronzanog i željeznog doba u centralnoj Bosni, sv. 1: Rano bronzano doba, str. 20-21.

27 Borivo Čović, "Velika gradina u Varvari - I. dio (slojevi eneolitika, ranog i srednjeg bronzanog doba)", u: Glasnik Zemaljskog muzeja (A), n. s., sv. XXXII., Sarajevo, 1977., str. 57-60.

28 Z. Marković, nav. dj., str. 128, T. 7 / B 2, 4-7, T. 8,1, T. 10, 1-4, T. 12, 3. 
Na prostoru promatrane kulturne regije ne postoje realne indicije koje bi potvrdile autohton razvoj licenske keramike, stoga se pretpostavlja njezino preuzimanje sa sjevera. ${ }^{29}$ Veze između ovoga tzv. južnog i sjevernog areala licenske keramike i dalje su predmetom rasprava, a kao glavni problem se nameću mehanizmi i pravci njezina širenja. ${ }^{30} \mathrm{Naj}$ izglednije kako je smjer širenja licenske keramike išao preko sjevera. No, problem je nedostatak kontaktnih zona koje bi dodatno podržale navedenu teoriju. Jer osim Poda i Gornje Tuzle ${ }^{31}$ ne postoje nalazišta licenske keramike na prostoru između tzv. južnoga i sjevernoga areala njezina rasprostiranja. Naravno, takvo stanje može biti posljedica slabe istraženosti ranoga i srednjega brončanog doba na prostoru sjeverno od Poda. Isto tako ne bi trebalo zanemariti niti ostale elemente koji idu u prilog postojanju razvijenih kontakata Poda sa sjeverom, s kojima je mogao stići licenski i ornament izveden utiskivanjem dvonitne uzice. ${ }^{32}$ Svakako, u tom pogledu na važnosti dobivaju nalazišta s prostora Slavonije. ${ }^{33}$ Nadalje, problem predstavlja i nedostatak licenske keramike na nalazištima između Poda i južnoga areala rasprostiranja licenske keramike, kao što su Varvara i Privala. Na kojima su dokumentirane višestruke korelacije $s$ južnim arealom rasprostiranja licenske keramike $s$ jedne, is Podom s druge strane. ${ }^{34}$ Nažalost, u ovome trenutku nedostaje više pouzdanih podataka uz pomoć kojih bi se sa sigurnošću mogao rekonstruirati točan smjer širenja licenske keramike na jug, s tim kako sjeverni smjer ostaje kao najrealnija opcija.

29 Borivoj Čović, "Regionalne grupe ranog brončanog doba", u: Alojz Benac (prir.), Praistorija jugoslavenskih zemalja, IV, Centar za balkanološka ispitivanja, Sarajevo, 1983., str. 158.

30 K. Vinski Gasparini, nav. dj., str. 490; Blagoje Govedarica, "Rano bronzano doba na području istočnog Jadrana", Djela, LXVII/7, Centar za balkanološka ispitivanja, Sarajevo, 1989., str. 167; B. Čović, Pod kod Bugojna - Naselje bronzanog $i$ željeznog doba u centralnoj Bosni, sv. 1: Rano bronzano doba, str. 24.

31 Borivoj Čović, "Rezultati sondiranja na preistorijskom naselju u Gornjoj Tuzli", u: Glasnik Zemaljskog muzeja (A), n. s., sv. XV./XVI., Sarajevo, 1961., T. XV, 8.

32 B. Čović, Pod kod Bugojna - Naselje bronzanog i željeznog doba u centralnoj Bosni, sv. 1: Rano bronzano doba, str. 24-25.

33 Usp. M. Dizdar, nav. dj; B. Marijan, nav. dj; Z. Marković, nav. dj.

34 Usp. B. Čović, Velika gradina u Varvari - I dio (slojevi eneolitika, ranog i srednjeg bronzanog doba), str. 57-60; B. Čović, "Posuška kultura", str. 75; B. Cović, Pod kod Bugojna - Naselje bronzanog i željeznog doba u centralnoj Bosni, sv. 1: Rano bronzano doba, str. 24-25 i d. Kao alternativni pravac širenja licenske keramike prema jugu, pojedini autori pretpostavljaju zapadni smjer. Usp. B. GovedARICA, nav. dj., str. 167. 
Također, za definiranje prirode i karaktera prodora licenskoga ornamenta na jug, postojeći kontekstualni podatci ne dopuštaju nam stvaranje nekoga solidnijeg interpretativnog modela, jer osim identifikacije same vremenske i prostorne dimenzije licenskog ornamenta, potrebno je identificirati i ostale popratne elemente koji su bili involvirani u proces njegova širenja. Stoga se u ovom trenutku moramo zadovoljiti s konstatacijom kako se radi o stilu ukrašavanja koji se kao jedna ornamentalna atrakcija vrlo brzo proširio, bez konkretnijih kulturnih implikacija. ${ }^{35}$ Pojavu licenskoga ornamenta u posuškoj kulturi svakako moramo promatrati kao posljedicu procesa horizontalne kulturne interakcije, zahvaljujući kojoj se licenski ornament uspješno uklopio i prilagodio mjesnim formativnim procesima. ${ }^{36}$

Promatrani ulomak se izdvaja prema činjenici kako se radi o rijetkom primjerku, poznatom u kulturnoj regiji, na kojemu je ornament valovnice izveden višestrukim utiskivanjem dvonitne uzice, a ne otkane vrpce tkanice. ${ }^{37} \mathrm{Uz}$ već iznesene stratigrafske potvrde, pojava ornamenta valovnica, izvedenih u licenskoj tehnici i u tehnici utiskivanja dvonitne uzice, dodatno povezuje ta dva načina ukrašavanja. U tom pogledu osobito su važni podatci s jednoslojnoga nalazišta Trostruka gradina na kojemu se ornamenti valovnice izvedene u licenskoj tehnici i one izvedene u tehnici utiskivanja dvonitne uzice javljaju jedni uz druge. Na prostoru kulturne regije keramiku ukrašenu licenskom tehnikom i utiskivanjem dvonitne uzice nalazimo unutar različitoga konteksta, od pogrebnoga (gomila), do naseobinskoga (gradine, spilje i tzv. vangradinska naselja koncentriranog i razbijenog tipa). ${ }^{38}$ Zaključno možemo potvrditi kako analizirani ulomak dodatno upotpunjuje oskudne podatke o bronča-

35 B. MARIJAN, nav. dj., str. 111.

$36 \mathrm{U}$ prilog tome najviše ide sljedeći podatak. Naime, makroskopskim promatranjem eksternih obilježja keramike posuške kulture posve je jasno kako je licenski ornament apliciran isključivo na proizvode tradicionalne, mjesne keramografije.

37 Valovnice na ulomcima s Trostruke gradine is položaja Kovačina također su izrađene utiskivanjem dvonitne uzice. Usp. B. Čović, "Posuška kultura", T. X, 5; I. ŠutA, nav. dj., sl. 6 .

38 Usp. B. Čović, "Posuška kultura", str. 75; DAMIR KLIŠKIĆ, "Prapovijest na području Dugopolja", u: Ante Gulin (prir.), Dugopolje: zbornik radova općine Dugopolje, sv. 1, Dugopolje - Zagreb, 2001., str. 64, T. III., 6-8; Marinko Tomasović, "Arheološki dokazi života na prostoru Biokova od razdoblja prapovijesti do srednjeg vijeka", u: Roman Ozimec (prir.), Biokovo, Zagreb - Makarska, 2008., str. 142, T. II, 2; Marinko Tomasović, Arheološka topografija lijeve strane donjeg toka Cetine, str. 242, sl. 26, T. I, 4-6; V. Katavić - A. Sunko Katavić - A. Devlahović, nav. dj., str. 46, kat. jed. 7; K. Mucić - N. KovačEvić BoKARICA, nav. dj., str. 130, kat. jed. 2; I. ŠUtA, nav. dj., str. 11-12, sl. 6. 
nom dobu kulturne regije, dok se Majića gradina potencijalno svrstava u red poznatih nalazišta posuške kulture, odnosno njezine Sovići faze.

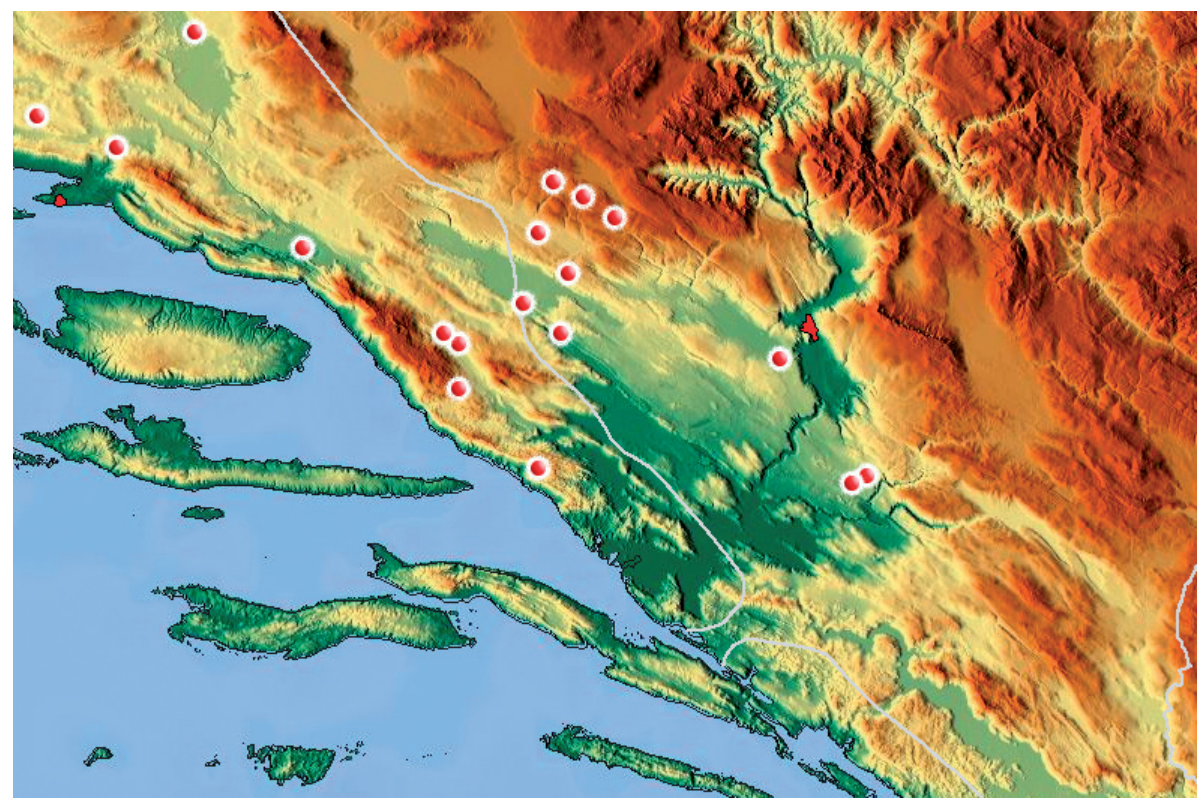

Karta 3. Nalazišta licenske keramike na prostoru promatrane kulturne regije (izvor: Google Maps - Relief Layers, prilagodio: autor) 


\section{The Majic hillfort (Drinovci) - a new finding site of the Litzen ceramics in Herzegovina}

\section{Summary}

The Majic hillfort (k. 478) is located in Drinovci, the Municipality of Grude. According to documented basic field data, such as natural position, topography and preserved elements of architecture, the hillfort fits into the category of hillforts, which makes one of the more prominent forms of Bronze Age in the East Adriatic cultural region. During reconnaissance of a wide area of the Majic hillfort, in its northern part with isolated artificial plateau a variety of fragments of pottery vessels were found. Most of the collected fragments are atypical, without elements that would serve their accurate cultural and chronological attribution. But one fragment stands out above all by its ornamental characteristics, a vessel neck fragment decorated with impressed complex textile pattern. Its macroscopic analysis shows a decorating technique which includes impression of twisted double cords (newer version of decorating schnur technique). The motifs include a combination of corrugated and horizontally laid prints. In the observed cultural region, such decorations are closely related to Litzen technique of decoration. In the analysis of primarily ornamental features of the observed fragments we find its closest analogy to the Posusje culture, precisely its Sovici phase (the site known as a Triple hillfort). Chronologically, it refers to the second half of the Early and the beginning of the Middle Bronze Age (Reinecke: Br. A2 - Br. B1). Further evidence that favors the setting of a relative chronological frame was obtained in the exploration of multilayer sites Pod A2 and Varvara A3. Original basic Litzen decorating technique cannot be verified within the cultural space of the region. It is therefore assumed that it was brought from the north, i.e. from its indigenous space. As the most likely direction of the Litzen decoration spreading to the south is the north-south direction, while we currently do not have enough reliable data on the reconstruction of the mechanisms and the nature of the Litzen decoration spread, due to a find is without stratigraphic confirmation. Thanks to $a$ priori its ornamental characteristics, the analyzed fragment is a strong and reliable chronological landmark in the observed cultural region.

Keywords: the Majic hillfort, litzen and schnur ceramics, the Posusje culture, the Bronze Age, Drinovci, Herzegovina. 